Conference Paper

\title{
The Effect of Cash Turnover, Account Receivable Turnover and Inventory Turn- over on ROA in Mining and Quarrying Sector Companies Listed in IDX from 2017-2019
}

\author{
Heliani, Risma Yulianti*, Vina Herdina, Fitri Mareta, Indah Purnamasari \\ Nusa Putra University, West Java, Indonesia
}

*Corresponding author:

E-mail:

risma.yulianti_ak18@nusaputra.ac.id

\begin{abstract}
The mining sector is a manufacturing company sector whose activities consist of extracting, processing and exploiting, and selling coal, minerals, metals, and natural gas. This research was conducted to determine whether ROA is affected by cash turnover, accounts receivable turnover, and inventory turnover using documentation as a data collection and a method of multiple linear regression analysis through SPSS data processing. The population used is the mining and quarrying sector companies listed on Indonesia Stock Exchange (IDX) from 2017-2019 totaling 43 companies. The purposive sampling method was used in determining the sample which resulted in 33 samples. The research shows that cash turnover, accounts receivable turnover and inventory turnover do not affect ROA because this is due to a decrease in the amount of production, cash flow constraints due to low turnover of accounts receivable, and low sales so that inventory turnover is slow and inventory costs are higher.
\end{abstract}

Keywords: ROA, cash turnover, account receivable turnover, inventory turnover

\section{Introduction}

Profit is one of the many purposes for establishing a company. Companies can meet other goals or targets by making a profit. Many factors influence financial performance, one of which is the company's survival. To find out a healthy financial performance, one way is to observe the company's proficiency in processing profits using the profitability ratio. Profitability is the ratio to see how efficient the management is in carrying out its operational activities to get profit during a certain period (Kasmir, 2014). The argument that the company's ability to generate profits is evaluated by the profitability ratio. According to Kasmir (2014), the role of profitability ratios for companies includes seeing the profits that the company gets during one period, seeing the development of company profits from year to year, and knowing company funds both own capital and loan capital used for production.

Financial performance is a performance parameter that assesses the analysis and the company has succeeded in getting a profit in the accounting period. Munawir (2012) argues that the purpose of a financial company is to see the ability to cover its debts at repayment and liquidation, the ability to earn profits for a certain period and to see the company's ability to stabilize its business by paying off the burden on its debt.

In this study, ROA is used as a parameter to measure profitability. ROA is a ratio to estimate a company's ability to use its assets to generate profits. A high ROA value will illustrate the company's good ability to utilize its assets so that the company's profits will get better because it gets a large return (Fahmi, 2013). According to Hendra and Raharja (2009), high and low ROA are caused by many factors such as cash, accounts receivable, and inventories. The amount of cash at least and the level of cash turnover indicates the use of cash in the company. The amount of cash held indicates that the company has not been effective in using it so that it will have an impact on profitability. High profits will be obtained if the cash turnover rate is high. As with accounts receivable and turnover, profits will increase

\section{How to cite:}

Heliana, Yulianti, R., Herdina, Matera, F., \& Wikantyoso, B. (2021). The effect of cash turnover, account receivable turnover and inventory turn-over on ROA in mining and quarrying sector companies listed in IDX from 2017-2019. $1^{\text {st }}$ ICEMAC 2020: International Conference on Economics, Management, and Accounting. NST Proceedings. pages 90-97. doi: 10.11594/ nstp.2021.1010 
if the proportion of receivables that have been allocated from creditors is also high so that the company will also have high profits. Likewise inventory, high inventory turnover will smooth the cash return with sales. Sales will increase if the inventory rotates quickly because this will minimize inventory costs and reduce the risk of loss levels due to stockpiling. High sales will increase the revenue generated. To estimate a company's ability to use its assets to earn a profit, researchers used indicators of cash turnover, accounts receivable turnover, and inventory turnover.

Cash turnover according to Kasmir (2015) is a ratio to assess a company's ability to use its cash to earn income. High the cash turnover in one period, the higher the income generated.

Accounts receivable turnover is the ratio to see the amount of costly turnover in one period that comes from accounts receivable (Kasmir, 2015). Company finances are in good shape if the turnover of accounts receivable in one period is running fast because the cash flow will run smoothly, thereby minimizing losses from the number of bad debts. Smooth cash flow can be used to finance sales for profit so that the company's profit will also increase.

Inventory turnover is the ratio to find out how efficient the company's inventory is (Sutrisno, 2012). Sales will increase if the inventory rotates quickly because this will minimize inventory costs and reduce the risk of loss levels due to stockpiling. High sales will increase the revenue generated.

The research is focused on mining and quarrying companies listed on the IDX for the 2017-2019 period. During Indonesia's rapid economic growth, the mining and quarrying sector has contracted since 2017. In the first quarter of 2019, Indonesia's economic growth increased to $5.01 \%$ compared to the previous year with the same quarter of $4.92 \%$, but this made the mining sector and excavation experienced a $-0.49 \%$ contraction as a result of several companies experiencing a decline in production and expiration of concentrate export permits.

From 2017 to 2019, the mining and quarrying sector contracted due to a decrease in the amount of production. The decrease in the amount of production was due to the decline in metal ore mining production by $25.93 \%$ and oil, gas, and geothermal by $4.11 \%$. This resulted in the mining and quarrying sector contracting in the first quarter by $2.65 \%$ and a decline in the second quarter by $1.70 \%$. The contribution to Gross Domestic Product (GDP) also decreased to $7.38 \%$ in the second quarter of 2019. This decrease in production had an impact on profitability because the company was unable to sell its products in large quantities so that the profits were not large. Because a decrease in the amount of production affects a decrease in the level of sales so that the level of company profitability can also decrease, therefore the researchers researched to analyze how mining and mining sector companies generate profitability by utilizing their assets such as cash turnover, accounts receivable turnover and inventory turnover.

This study intends to see the effect of cash turnover, accounts receivable turnover, and inventory turnover on ROA in the case of the mining and quarrying sectors listed on the IDX for the 2017-2019 period. This study also aims to add insight for researchers and train scientific thinking. This study can also be used as reference material for investors before making investment decisions.

\section{Literature Review \\ Signaling theory}

Signal theory is a shareholder's point of view, which originates from the information provided by the management department of the company, this point of view regarding the company's opportunities to increase corporate value in the future (Brigham \& Houston (2014). In his research, Spence said that signal theory is a signal given by the sender or management to the recipient or stakeholders in the form of financial reports to predict company opportunities. This signal theory can be used to show shareholders the company's financial performance. Therefore, this signal will make it easier for shareholders to see the development of a company's financial performance which will make it easier for them to make decisions. In this study, profitability is used as a signal that management will share with shareholders. This profitability describes the company's ability to make profits using its assets. High profitability indicates that the company's financial performance is in good condition, so that good financial performance can be used by management to send good signals to shareholders (Fahmi, 2013).

\section{Return On Assets (ROA)}

Return on assets is a ratio that describes the capability of a company to benefit from its assets. Increasing the ROA value, of course, will increase the benefits you get. This is because the level of 
return on investment is getting bigger, therefore ROA is also used to describe how far the company's ability to make profitability from available assets. Sutrisno (2012) argues that ROA can be calculated by dividing earnings before interest and Taxes by the company's total assets which are then multiplied by $100 \%$. Sutrisno (2012) argues that ROA can be calculated by:

$$
\mathrm{ROA}=\frac{\text { EBIT }}{\text { Total Asset }} \times 100 \%
$$

\section{Cash turnover}

Cash turnover according to Kasmir (2015) is the reliability of cash in describing the extent to which a company uses its cash in one period to earn revenue. The higher the amount of cash turnover in one period, the higher the income generated. Cash is included in the company's assets, which is a divider in calculating ROA. The fast turnover of cash will be a measure of the company's success in using cash. Cash turnover during one period according to Kasmir (2015) can be calculated by dividing net sales by the average cash. Cash turnover during one period according to Kasmir (2015) can be calculated by:

$$
\begin{aligned}
& \text { Cash Turnover }=\frac{\text { Net Sales }}{\text { Cash average }} \\
& \text { Average cash }=\frac{\text { Begining of Year Cash+End of Year Cash }}{2}
\end{aligned}
$$

\section{Account receivable turnover}

Accounts receivable turnover is the number of accounts receivable turnover each year in a company related to the collection period of accounts receivable. Herry (2012) argues that accounts receivable turnover is usually used to calculate the time from the receivables collection period during one accounting period. A good financial condition is described by the fast turnover of accounts receivable in one period, due to the low number of uncollectible accounts that make cash flow smooth. When cash flow is smooth, sales will increase, increasing the company's revenue. Apart from cash, receivables are also included in the company's assets so that they become a divider when calculating ROA. According to Sutrisno (2012) accounts, receivable turnover can be calculated by :

$$
\begin{gathered}
\text { AR Turnover }=\frac{\text { Net Sales }}{\text { average Account Receivable }} \\
\text { Average cash }=\frac{\text { Begining of Year Cash }+ \text { End of Year Cash }}{2}
\end{gathered}
$$

\section{Inventory turnover}

Inventory turnover is a comparison to calculate the entire turnover of funds in one period that is invested in inventory (Kasmir, 2015). The normal production cycle can be viewed from the fast inventory turnover. Its agile turnover is considered very good because it indicates rapid sales activity. The fast inventory turnover will also increase sales activity. In addition to cash and receivables, inventory is also included in the company's asset component, which of course will be a divider in calculating ROA. The fast inventory turnover in one period is a measure of the success of a company's production cycle. According to Sutrisno (2012), cash turnover during one period can be calculated by dividing the cost of goods sold by the average inventory. According to Sutrisno (2012), cash turnover during one period can be calculated by :

$$
\begin{aligned}
& \text { Inventory Turnover }=\frac{\text { Cost Goods Sold }}{\text { average Inventory }} \\
& \text { Average Inventory }=\frac{\text { Begining of Year Cash }+ \text { End of Year Cash }}{2}
\end{aligned}
$$




\section{Hypothesis}

The proposed hypotheses include :

$\mathrm{H} 1=$ Cash turnover affects ROA

$\mathrm{H} 2=$ Accounts receivable turnover affects ROA

$\mathrm{H} 3$ = Inventory turnover affects ROA

\section{Material and Methods}

This research is a quantitative study because it uses numerical data as an analysis instrument. Documentation is used as a data collection technique and makes Return on Assets (ROA) the dependent variable and cash turnover, accounts receivable turnover, and inventory turnover independent variables.

Utilizing secondary data which is the source of data from the annual financial statements of companies in the mining and excavation sector for the 2017-2019 period published on www.idx.co.id totaling 43 companies. Because the research was conducted in three periods so that the population numbered 129. The sample collection technique was purposive sampling based on certain criteria, then a sample of 33 samples was obtained. The criteria used include 1) Mining and quarrying companies listed on the IDX for the period 2017 - 2019. 2) Companies do not report financial reports continuously in 2017 - 2019. 3) Mining and quarrying sector companies do not report complete account components in 2017 - 2019. 4) The company does not use rupiah in its financial statements. 5) Outlier data.

To prove whether there is an impact of cash turnover accounts receivable turnover and inventory turnover on ROA, multiple linear analysis methods are used. To complete a good multiple linear regression model, the data normality test, multicollinearity test, autocorrelation test, t-test, and coefficient of determination were carried out.

\section{Results and Discussion \\ Data normality test}

One-Sample Kolmogorov-Smirnov was used to check the normality of the data with 5\% si. The following are the results of the data normality test conducted in this study:

Tabel 1. One-sample kolmogorov-smirnov test

\begin{tabular}{cc}
\hline & ROA \\
\hline $\mathrm{N}$ & 33 \\
Kolmogorov-Smirnov $Z$ &, 635 \\
Asymp. Sig. (2-tailed) &, 814 \\
Source: data processed by SPSS & \\
\hline
\end{tabular}

Sourced in table 1, it is known that the data is spread normally because of the Sig. $0.814>0.05$. So it can be concluded that the distribution of residual values in all regression equation models is stated to be normally distributed.

\section{Multicollinearity test}

The multicollinearity test is carried out, which is to check whether there is a correlation between the independent variables.

Tabel 2. Coefficients

\begin{tabular}{ccc}
\hline Model & \multicolumn{2}{c}{ Collinearity Statistics } \\
& Tolerance & VIF \\
\hline Cash Turnover &, 945 & 1,058 \\
Account Receivable Turnover &, 953 & 1,049 \\
Inventory Turnover &, 989 & 1,011 \\
\hline
\end{tabular}

Source: data processed by SPSS 
Based on table 2, it was found that there was no multicollinearity between the independent variables because the VIF value was $<10$ and the tolerance value $>$ was 0.10 . So it can be concluded that the regression model used avoids multicollinearity problems.

\section{Autocorrelation test}

The autocorrelation test is a method used to find out whether the data used has errors related to data in the previous period. One of them is the Run Test method.

Tabel 3. Runs test

\begin{tabular}{cc}
\hline & ROA \\
\hline Total Cases & 33 \\
Number of Runs & 18 \\
$Z$ &, 005 \\
Asymp. Sig. (2-tailed) &, 996 \\
\hline
\end{tabular}

Source: data processed by SPSS

Based on table 3, the Sig. 0.996>0.05. Thus it can be concluded that the data used is quite random so that there is no autocorrelation problem in the data being tested.

\section{Test the coefficient of determination (R2)}

The implementation of the coefficient of determination (R2) test to explain the modification of variables by looking at the capabilities of the regression model.

Tabel 4. Model summary

$\mathrm{R} \quad \mathrm{R}$ Square $\quad$ Adjusted $R$ Square Std. Error of the Estimate

$\begin{array}{lll}, 177^{\mathrm{a}} & , 031 & -, 101\end{array}$

, 0429290

Source: data processed by SPSS

Based on the table above, the $\mathrm{R}$ Square value is 0.031 . The meaning of the capability of the independent variable in influencing the dependent variable is only $3.1 \%$, while $96.9 \%$ is influenced by variables that are not examined.

\section{The t-test}

The t-test was carried out to see the influence of the independent variables spatially on the dependent variable which was processed using SPSS assistance. The following are the results of the ttest in this study:

Tabel 5. Uji-t

\begin{tabular}{ccc}
\hline Variable & $\mathrm{t}$ & Sig. \\
\hline Cash Turnover & -.390 & .701 \\
Account Receivable Turnover & .570 & .575 \\
Inventory Turnover & .257 & .799 \\
\hline
\end{tabular}

Source: data processed by SPSS

Based on the results of the $t$ statistical test in the table above, it can be concluded that the variables of cash turnover, accounts receivable turnover and inventory turnover do not affect ROA because all variables have a sig $>0.05$.

\section{Effect of Cash Turnover on ROA}

Based on the results of partial hypothesis testing in the table above, it is revealed that cash turnover does not affect ROA. This is because the results of the t-test statistic show that the significance value of cash turnover is 0.701 . This value is greater than the real rate value of 0.05 or $0.701>0.05$. This condition 
proves that hypothesis 1 is rejected. So, it can be concluded that the variable $\mathrm{x} 1$, namely cash turnover, does not affect the dependent variable, namely ROA in the case of mining and quarrying companies. These results are in line with research by Fitriana et al. (2020), and Widiastuti and Rusliansyah (2019) which reveal that cash turnover does not affect ROA.

Table 6. Cash turnover data

\begin{tabular}{crrr}
\hline Emiten & $\mathbf{2 0 1 7}$ & $\mathbf{2 0 1 8}$ & $\mathbf{2 0 1 9}$ \\
\hline ANTM & 1,92 & 5,12 & 8,24 \\
CITA & 15,31 & 61,49 & 48,09 \\
DKFT & 0,89 & 29,99 & 28,82 \\
ELSA & 6,04 & 8,16 & 10,64 \\
FIRE & 16,87 & 25,34 & 31,62 \\
PKPK & 8,30 & 6,14 & 10,61 \\
PTBA & 5,38 & 4,29 & 3,94 \\
RUIS & 17,71 & 17,54 & 22,42 \\
SMMT & 3,48 & 6,03 & 4,11 \\
SMRU & 28,04 & 12,61 & 14,13 \\
TINS & 9,59 & 10,28 & 16,19 \\
ZINC & 10,91 & 11,18 & 13,22 \\
\hline
\end{tabular}

Cash turnover does not affect ROA in mining and quarrying sector companies because cash turnover in companies in this sector has fluctuated on average. It can be seen in table 6 that only 5 out of 12 companies experienced an increase in cash turnover and the rest experienced fluctuation. The fluctuations that occur are caused by a decrease in the amount of production. Low cash turnover illustrates the inefficient use of cash because of the large amount of cash that is stored or not used.

\section{Effect of accounts receivable turnover on $\mathrm{ROA}$}

Based on the results of partial hypothesis testing in Table 5, it is revealed that the value of accounts receivable turnover does not affect ROA. This is because the results of the t-test statistic showed that the significance value of accounts receivable turnover was 0.575 . This value is greater than the real rate value of 0.05 or $0.575>0.05$. This condition proves that hypothesis 2 is rejected. So it can be concluded that the variable $\mathrm{x} 2$, namely receivables turnover, does not affect the dependent variable, namely ROA in the case of mining and quarrying companies. This result is in line with the research of Nurafika and Almadany (2018) which states that receivables turnover does not affect ROA.

Table 7. Receivable Turnover Data

\begin{tabular}{crrr}
\hline Emiten & 2017 & 2018 & \multicolumn{2}{r}{2019} \\
ANTM & 10,68 & 17,98 & 22,87 \\
CITA & 3,40 & 10,05 & 14,55 \\
DKFT & 0,62 & 3,72 & 5,49 \\
ELSA & 5,04 & 4,68 & 4,57 \\
FIRE & 2,19 & 6,84 & 13,17 \\
PKPK & 0,53 & 0,37 & 1,22 \\
PTBA & 5,10 & 5,21 & 7,91 \\
RUIS & 3,90 & 4,03 & 4,19 \\
SMMT & 21,14 & 68,41 & 88,28 \\
SMRU & 1,38 & 5,95 & 2,97 \\
TINS & 7,16 & 6,02 & 10,26 \\
ZINC & 12,13 & 8,75 & 4,58 \\
\hline
\end{tabular}

Based on the table above, accounts receivable turnover does not affect ROA in mining and quarrying sector companies because two companies have experienced a significant decrease in receivables 
turnover. Even though in this case, the average company experienced an increase in accounts receivable turnover each year. Low accounts receivable turnover can result in choked-up cash flow.

\section{Effect of Inventory Turnover on ROA}

Based on the results of partial hypothesis testing in Table 5, it is revealed that the value of inventory turnover does not affect ROA. This is because the results of the t-test statistic showed that the significance value of inventory turnover was 0.799 . This value is greater than the real rate value of 0.05 or $0.799>0.05$. This condition proves that hypothesis 3 is rejected. So, it can be concluded that the variable $\mathrm{x} 3$, namely inventory turnover, does not affect the dependent variable, namely ROA in the case of mining and quarrying companies. These results are in line with Sarjito et al. research (2017) which reveals that inventory turnover does not affect ROA.

Table 8. Inventory turnover data

\begin{tabular}{crrr}
\hline Emiten & 2017 & 2018 & 2019 \\
\hline ANTM & 9,56 & 15,36 & 17,96 \\
CITA & 1,45 & 4,68 & 9,83 \\
DKFT & 0,31 & 1,69 & 1,38 \\
ELSA & 43,85 & 50,26 & 44,09 \\
FIRE & 18,65 & 49,72 & 27,68 \\
PKPK & 0,87 & 0,75 & 3,25 \\
PTBA & 17,24 & 15,63 & 14,85 \\
RUIS & 167,99 & 204,81 & 126,22 \\
SMMT & 20,38 & 42,73 & 51,81 \\
SMRU & 18,01 & 72,93 & 35,34 \\
TINS & 3,82 & 3,34 & 3,60 \\
ZINC & 5,12 & 7,97 & 9,97 \\
\hline
\end{tabular}

Inventory turnover does not affect ROA in mining and quarrying sector companies because of the fluctuations in average inventory turnover in companies in this sector. It can be seen in table 8 that only 4 out of 12 companies experienced an increase in cash turnover and the remaining 8 companies experienced fluctuation. This results in lower sales and leads to higher inventory costs.

\section{Conclusion}

This study succeeded in revealing that cash turnover, accounts receivable turnover, and inventory turnover did not affect ROA. This is for the following reasons fluctuations that occur in cash turnover which make cash turnover on ROA do not affect, a significant decrease in the value of accounts receivable turnover so that inventory turnover does not affect ROA, and fluctuations that occur in inventory turnover that make inventory turnover on ROA do not affect.

The suggestions that researchers try to give can be considered for further research such as expanding the object of research and the number of research periods and increasing the analytical methods used. This research is also expected to have benefits as consideration for investors in taking action before investing in the mining and quarrying sector.

\section{Acknowledgment}

We thank all valuable comments from the anonymous reviewer and conference participants at $1 \mathrm{st}$ ICEMAC 2020. Sukabumi, 19-20 December 2020

\section{References}

Brigham, E. F., \& Joel, F. H., (2014). Basics of Financial Management. Book 1. Edition 11. Jakarta: Salemba Empat.

Fahmi, I. (2013). Financial Statement Analysis. Bandung: Alfabeta

Fitriana, I. D., Wijayanti, A., \& Rachmawati, R. (2020). Effect of cash turnover, accounts receivable turnover and inventory turnover on profitability. National Seminar on Management, Economics and Accounting. Surakarta Batik Islamic University.

Hendra, S., \& Raharja, P. (2009). Financial Management and Accounting. Jakarta: Four Salemba. 
Herry, S. E, (2012) Financial Statement Analysis, Jakarta: PT Bumi Aksara

Kasmir. (2014). Financial Statement Analysis. Jakarta: PT. Rajagrafindo Persada.

Kasmir. (2015). Financial Statement Analysis. Jakarta: Rajawali Press

Munawir, S. (2012). Financial Information Analysis, Yogyakarta: Liberty.

Nurafika, R. A., \& Almadany, K. (2018). The Effect of Cash Turnover, Accounts Receivable Turnover and Inventory Turnover on Profitability in Cement Companies. Journal of Accounting and Business, 4 (1) 2243-3071

Sarjito, S., Ruly, R., Dedi, R. (2017). Effect of Cash Turnover, Accounts Receivable Turnover and Inventory Turnover on Profitability. Accountability: Journal of Accounting Science, 10 (2), 858-979.

Sutrisno. (2012). Theory, Concepts and Applications of Financial Management. Yogyakarta: ECONISIA.

Widiastuti, H. B., \& Rusliansyah. (2019). The Effect of Cash Turnover, Accounts Receivable Turnover and Inventory Turnover on Profitability at Mining Companies Listed on the Indonesia Stock Exchange. Kalimantan: Journal of Accounting Science, 4(3), 19-29 